\title{
Będę singielka jak moja mama, czyli o cywilizacyjnych zmianach w języku dzieci w wieku przedszkolnym
}

\author{
Nie ma nic lepszego niż język, \\ który jest łącznikiem życia społecznego, \\ kluczem do wiedzy, organem prawdy i rozsądku.
}

Ezop

Przytoczone motto wręcz doskonale wpisuje się w problematykę konwersatorium, w którym uczestniczymy. Sądzimy jednak, że jeszcze bardziej można je odnieść do języka dziecka, które właśnie poprzez język uczy się uczestnictwa w życiu społecznym, zdobywa wiedzę o świecie, a nade wszystko jest naiwnie szczere i ufne wobec tego świata.

Rozważania nasze rozpoczniemy od zacytowania kilku wielce charakterystycznych, a przy tym istotnych dla dalszego ciągu, dziecięcych wypowiedzi. W każdej parze jest wypowiedź „stara” (Zgółkowa 1986, s. 26) ${ }^{1}$, a po niej „nowa"

1. Tatuś kupi sobie zastawę, może skodę, a najlepiej poloneza, tylko teściowa musi coś dać (ch. 6,2).

2. Jak będę duży, to se kupię audicę i będę woził mamę do pracy; to będzie fura! (ch. 5,3).

3. Jak ojciec umrze, to potem sprzedam gospodarkę, się ożenię, na bloki pójdę w Poznaniu (ch. 6,8).

4. Wuja dopiero drugą chatę buduje, a my już mamy trzy chaty - i to jakie! (ch. 4,3).

${ }^{1}$ Są to wypowiedzi pozyskane od dzieci w wieku przedszkolnym w latach 1980-1983.

2 Wypowiedzi nowe pochodzą $\mathrm{z}$ analogicznych wypowiedzi dziecięcych pozyskanych w latach 2010-2013. 
5. Pojedziemy na wieś, no będą mordować świnię, to się — wie pani - coś zje (dz. 5,11).

6. Najbardziej lubię jeść frytki z nuggetsami, też może być spaghetti, lubię też marchewkę $\mathrm{z}$ ananasem (ch. 5,5).

7. Beata mówiła, że jej cioci urodziło się dziecko, a nie ma męża i wszyscy mówili, że to taki wstyd (dz. 6,5).

8. [dialog] — Moja mama jest singielką

- A co to jest singielka?

— No że nie ma męża i ma dziecko (dz. 5,11-5,7).

Przyjęta perspektywa diachroniczna polega na zestawieniu wypowiedzi formułowanych przez dzieci w wieku przedszkolnym w latach 1980-1983 z wypowiedziami uzyskanymi od dzieci w tym samym wieku, ale trzydzieści lat później. Pozwala ona na sporządzenie rejestru rozbieżności leksykalnych, ale i obyczajowych, które da się zaobserwować na przestrzeni wyznaczanej przez dwa kolejne pokolenia. Szczegółowe zmiany, które w tych przestrzeniach zaszły, są wielorakie i były już wielokrotnie opisywane w różnych ujęciach (m.in. Miodek (red.) 1996; Warchala, Krzyżyk (red.) 2008; Michalewski (red.) 2001; Pisarek (red.) 1999; Mazur (red.) 1999, 2000; Gajda, Markowski, Porayski-Pomsta (red.) 2005; Bralczyk, Mosiołek-Kłosińska (red.) 2001; Markowski, Pawelec (red.) 2012; Mikołajczuk, Pawelec (red.) 2007; Panasiuk, Woźniak (red.) 2013; Ożóg 2004). Mają one oczywisty wpływ na sferę języka - zwłaszcza leksyki i frazeologii. Ale tu proponujemy spojrzenie niejako odwrotne: jaki obraz zmian da się namalować, stosując narzędzia językoznawcze. Oznacza to propozycję zastąpienia badań ankietowych, sondażowych itp. spojrzeniem na sytuację Polaków przez językową „,dziurkę od klucza”. Pozwalamy sobie sądzić, że wyniki takiego podejścia są znacznie ciekawsze niż dociekania ekonomistów, kulturoznawców, politologów, socjologów itp. Dotyczy to zwłaszcza badań prowadzonych w obszarze języka dzieci w wieku przedszkolnym przez psychologów (psycholingwistów) (zob. Smoczyńska 1998; Haman, Fronczyk, Łuniewska 2014; Haman, Fronczyk, Miękisz 2010). Żadne ankiety lub z góry zaprojektowane Obrazkowe Testy Stownikowe (zob. Haman, Fronczyk 2012) nie dają możliwości zbadania autentycznego, czynnego słownika dzieci w wieku przedszkolnym. W testowych badaniach psychologów proponuje się arbitralne ograniczenie słownika dziecka do wybranych części mowy - rzeczowniki, czasowniki i przymiotniki — i do z góry zaplanowanych przez eksploratora haseł.

Natomiast językoznawcę interesują autentyczne, spontaniczne wypowiedzi dziecięce pozwalające na empirycznie adekwatny opis dziecięcego świata językowego. Oczywiście część tego świata zapożyczona jest od dorosłych (np. w rodzinie dziecka). Zastosowanie perspektywy diachronicznej (np. na przestrzeni jednego pokolenia) daje możliwość konfrontacji międzypokoleniowej. Badania przepro- 
wadzone przed laty (1980-1983) mogą stanowić podstawę dzisiejszej rekonstrukcji tamtej sytuacji — najszerzej rozumianej. Po drodze był rok 1989, który wielu Polaków uważa za jedną z najważniejszych cezur w dziejach najnowszych. Dzieci w wieku przedszkolnym badane dzisiaj mają już za sobą refleksje dorosłych (z pokolenia ich rodziców) i przyszły niejako na gotowe. Warto więc spojrzeć na kondycje obu tych pokoleń z perspektywy czasu przeszłego dokonanego.

Wypowiedzi współczesnych dzieci są i będą nadal gromadzone. Jak dotąd dysponujemy korpusem tekstowym o objętości ponad 100000 wyrazów. Obejmuje on autentyczne wypowiedzi dziecięce w wersji mówionej, spontanicznej. Docelowo ma on mieć znacznie większą objętość, ale dla zamierzonych badań wyekscerpowana będzie losowa próba zawierająca 100000 wyrazów, ponieważ będzie można formułować wnioski, odwołując się do opracowań leksykograficznych (i nie tylko) sprzed lat. Ambicją osób zaangażowanych w te badania jest m.in. pokazanie, $w$ jakich szczegółowych dziedzinach zmiany są wyraziste, choć na co dzień raczej niezauważalne. Wszyscy wiemy, jakie otwarcie na świat spowodowane zostało przez upowszechnienie się technik informatycznych. Dużo mniej wiemy zaś na temat kierunków podróży turystycznych (np. znanych dzieciom nazw kontynentów i państw) lub dziecięcych kulinariów.

Konfrontacji należy poddać wiele szczegółowych aspektów leksykograficznych i leksykologicznych — od liczby haseł począwszy. Na razie porównania mogą być cząstkowe, jako że zostały oparte na próbie dziesięciokrotnie mniejszej niż w słowniku z roku 1987 (zob. Zgółkowa, Bułczyńska 1987). Przed laty uzyskano dane od 625 osób (320 chłopców i 332 dziewczynek), co dało słownik o objętości 6123 haseł. Obecnie analizowany dziesięciotysięczny korpus jest oparty na tekstach wypowiedzianych przez 328 osób (116 chłopców i 122 dziewczynki). Po szczegółowym opracowaniu dało to już słownik o objętości 2185 haseł. Oczywiście przyrost haseł nie jest proporcjonalny statystycznie, ponieważ każde następne 10000 wyrazów przynosi coraz mniej haseł nowych, a coraz wyższą frekwencję haseł częstych i najczęstszych.

Nie te porównania są jednak najciekawsze. O wiele ciekawsza jest konfrontacja. Wśród 2185 haseł współczesnych odnotowano aż 738 takich, które w pełnej, stutysięcznej próbie sprzed lat nie występują. Oczywiście dotyczy to przede wszystkim haseł rzadkich i bardzo rzadkich, aż po singlowe (nomen omen) włącznie. Bardzo z grubsza można zatem ocenić, jakie wyniki pojawią się po uwzględnieniu całej stutysięcznej próby gromadzonej obecnie. Potwierdza to chyba z naddatkiem - hipotezę o ogromnym przyroście słownictwa dziecięcego w perspektywie pokolenia. Co ciekawsze - bardzo pogłębił się poziom zanurzenia słownictwa dziecięcego w słownictwie dorosłych, co postaramy się pokazać, posiłkując się autentycznymi przykładami. Do jednego - zacytowanego wyżej — przykładu warto się jednak już teraz odwołać. Chodzi bowiem o świat wartości: panna $z$ dzieckiem przez wiele polskich pokoleń była potępiana. Dzisiaj singielka — to brzmi dumnie. 
Tempo zmian dokonanych na przestrzeni pokolenia każe zrewidować słynną tezę wypowiedzianą przed stuleciem przez J. Baudouina de Courtenay, zgodnie z którą język dzisiejszych dzieci (np. w wieku przedszkolnym) jest projekcją języka dorosłych w następnym pokoleniu. Obecnie dokonywane konfrontacje międzypokoleniowe pokazują, jak wiele nowych słów przybyło w słowniku (a przecież i w świadomości) dzisiejszych przedszkolaków w stosunku do słownika używanego przez poprzednie pokolenie. Tym bardziej ryzykowne wydają się próby prognozowania w przód, np. na następne trzydziestolecie.

Przejdźmy teraz do wskazania tych pól wyrazowych (tematycznych), w których można zauważyć szczególnie wyraziste zmiany w repertuarze leksyki dziecięcej. Poniższe wyliczenie należy traktować — ze względów wielokrotnie wyżej podkreślanych — jako egzemplifikacyjne, a w żadnym razie nie ostateczne. Niektóre z nich mogą się wydawać dość oczywiste nawet bez szczegółowych badań leksykologicznych, wszakże szczegóły słownikowe bywają już zaskakujące. Oto zatem kilka takich dziedzin życia:

1. Podróże niemal po całym świecie i wiedza geograficzna;

2. Technologie komputerowe, informatyczne, media elektroniczne;

3. Globalizacja językowa, zwłaszcza w zakresie posługiwania się językiem; angielskim oraz $\mathrm{w}$ zakresie internacjonalizmów;

4. Zdrowie, kosmetyka, wygląd;

5. Kulinaria (z najbardziej wyszukanymi włącznie);

6. Rozrywki i wypoczynek;

7. Wiedza o środowisku, ekologii, świecie roślinnym i zwierzęcym;

8. Uczestniczenie (nierzadko zapewne na zasadzie przymusu) w świecie dorosłych.

Oczywiście nie sposób precyzyjnie wyznaczyć kierunku związków między życiem a słownictwem. Dziecko może używać nazw takich jak kalmary lub Bangkok, niekoniecznie dlatego, że dokładnie zna ich semantykę, ale ze względów, by tak powiedzieć, snobistycznych (czyli szpanerskich). I tu pojawia się wspomniane zjawisko globalizacji, którego mechanizmy językowe są nader skomplikowane. $\mathrm{Z}$ jednej strony - na przykład - dzieci znakomicie znają z autopsji nazwę galeria (i to raczej nie w związku z ekspozycją plastyczną) i nazwy supermarketów spotykanych nie tylko w większości polskich i niepolskich miast. Z drugiej jednak globalizacja jest niejako wymuszona instytucjonalnie (dzieci uczęszczające do przedszkola powszechnie uczestniczą w lekcjach języka angielskiego), ale i środowiskowo. Oto przykłady ilustrujące oba trendy:

Zaskoczę cię, umiem to samo śpiewać po angielsku, w przedszkolu uczę się angielskiego (ch. 4,7).

[opowiadanie o wczasach] .... czerwony to red i mówiłem tak: orange juice please and red syrop (ch. 5,11). 
...mam płytę boogie-woogie (ch. 4,6).

...uzbierałbym sobie full pieniążków... (ch. 5,8).

....a kiedy wróci daddy [dejdi]... (dz. 4,3).

W podanych wyżej przykładach widać — jak w soczewce — wspomniane trendy: angielski służy jako lingua franca (także za granicą), a jednocześnie jego znajomość to powód do dumy, nieznajomość — odwrotnie. Przy czym na razie jest to wersja polanglo, makaronizowana. Marzenia o znajomości języków są jednak bardzo silne, do tego stopnia, że budzi podziw:

Ten pan mówił po hiszpańsku, po angielsku, po niemiecku i po polsku; to dopiero językoznawca! (dz. 5,0).

Globalizacja lokalna, to nazwy o zasięgu międzynarodowym umieszczane w kontekście polskim:

(a) gry, zabawy, zabawki, np. Ferby, My Little Pony, Monster High, Spiderman, Star Wars, Hello Kitty, breakdance;

(b) technika komputerowa to nie tylko komputer, ale też komp, tablet, laptop, skype, Xbox, aplikacja w telefonie, Facebook, zalogować się na fejsie, rozmawiać na Skypie;

(c) starsze i nowsze zapożyczenia, których nie ma jeszcze przed trzydziestu laty, np. grill, piknik, bankomat, western, weekend, casting, pampers, origami; wiesz, to byto nie fair; okey;

(d) nazwy geograficzne, a wśród nich: Anglia to jest taka wyspa, tata wyjeżdża tam do pracy (ch. 5,2), tata musi pracować w Szwecji teraz (ch. 5,11), w Anglii jest Legoland (sic!) oraz kierunki podróży wakacyjnych - Afryka, Hiszpania, Majorka, Teneryfa, Islandia, Indie, Portugalia, Rosja, Sardynia; tu dodać należy słowo autostrada jako zaskakująco częste oraz nazwy marek samochodowych BMW, Audi (audica), Ford, Mercedes, Opel;

(e) nazwy sklepów, zwłaszcza sieciowych, np. Tesco, Kaufland, Lidl, McDonalds, w tym także rodzimych Piotr i Pawet, Galeria Nowa MM, Smyk;

(f) nazwy potraw, słodyczy, napojów, takich jak: żelki, coca-cola, frytki, jogurt, Mamba, cola [także rodzaj gumy do żucia], mufinka, orkiszowy [chleb], gofr, danonki, popcorn, hamburger, chipsy, snickers, cornflakes, hot-dog, koktajl, arbuz, bakłażan, chińszczyzna, pomidorówka; warte odnotowania jest także to, że dzieci przyznają się do znajomości takich wyrazów, jak wino, piwko, a nawet przy stole domagają się wódki w wersji a ja jódki (dz. 2,6).

Zmierzając do konkluzji, proponujemy powrót do Ezopowego motta. Słownik dzisiejszych kilkulatków jest zaskakująco bogatszy niż ten używany przez poprzednie pokolenie, które też miało lat kilka. Dotyczy to niemal wszystkich pól wyrazowych, nawet w zakresie tak wyszukanym, jak niepetnosprawny, dorodny, dostojny, przeszczep, lotos [pozycja], naburmuszony, poroże. Abstracta 
reprezentują w tym słownictwie np. medytacja, medytować, tolerancyjny, dumać, wyobraźnia. Obok nich pojawiają się skrajne kolokwializmy, takie jak np. dycha [dziesięć złotych], dyska [dyskoteka], kasa [pieniądze], fura [samochód].

Ezop proponował traktować język jako „organ rozsądku”. Okazuje się, że dzieciom tego rozsądnego korzystania z języka nie brakuje. Oto charakterystyczne świadectwo pojawiające się w wypowiedzi pięcioletniej dziewczynki, która odmawiając dalszej rozmowy, uzasadniła w ten oto sposób:

Moja wyobraźnia dzisiaj odpoczywa, bo jest niedziela.

Warto, aby dorośli - zwłaszcza językoznawcy — wyobrazili sobie, rozsądnie odpoczywając $w$ niedzielę, jakie zmiany cywilizacyjne zajdą za sprawą języka dzisiejszych dzieci w wieku przedszkolnym w naszej rzeczywistości za kolejnych trzydzieści lat.

\section{Bibliografia}

Bralczyk J., Mosiołek-Kłosińska K. (red.) (2001), Zmiany w publicznych zwyczajach językowych, Warszawa.

Gajda S., Markowski A., Porayski-Pomsta J. (red.) (2005), Polska polityka komunikacyjnojęzykowa wobec wyzwań XXI wieku, Warszawa.

Haman E., Fronczyk K. (2012), Obrazkowy Test Stownikowy - Rozumienie (OTSR), Gdańsk.

Haman E., Fronczyk K., Łuniewska M. (2014), Wykorzystanie pojęcia normy w badaniach ilościowych nad rozwojem stownika umystowego, „Poradnik Językowy”, z. 4, s. 39-53.

Haman E., Fronczyk K., Miękisz A. (2010), Ocena stownictwa u dzieci w wieku przedszkolnym, „Psychologia Rozwojowa” 15, s. 21-45.

Markowski A., Pawelec R. (red.) (2012), Oblicza polszczyzny, Warszawa.

Mazur J. (red.) (1999), Polska polityka językowa na przetomie tysiacleci, Lublin.

Mazur J. (red.) (2000), Słownictwo współczesnej polszczyzny w okresie przemian, Lublin.

Michalewski K. (red.) (2001), Wspótczesna leksyka, Łódź.

Mikołajczuk A., Pawelec R. (red.) (2007) Na językoznawczych ścieżkach, Warszawa.

Miodek J. (red.) (1996), O zagrożeniach i bogactwie polszczyzny, Wrocław.

Ożóg K. (2004), Polszczyzna przełomu XX i XXI wieku. Wybrane zagadnienia, Rzeszów.

Panasiuk J., Woźniak T. (red.) (2013), Język - człowiek - społeczeństwo, Lublin.

Pisarek W. (red.) (1999), Polszczyzna 2000. Orędzie o stanie języka na przełomie tysiącleci, Kraków.

Smoczyńska M. (1998), Krakowskie dane językowe dzieci w systemie CHILDES, [w:] Studia z psychologii rozwojowej i psycholingwistyki, Kraków.

Warchala J., Krzyżyk D. (red.) (2008), Polska polityka językowa w Unii Europejskiej, Katowice.

Zgółkowa H. (1986), Czym język za młodu nasiąnie..., Poznań.

Zgółkowa H., Bułczyńska K. (1987), Stownictwo dzieci w wieku przedszkolnym. Listy frekwencyjne, Poznań. 


\section{„I will be a single-woman like my Mummy”, or about civilization changes in language using by pre-school children}

\section{Summary}

The main aim of this paper is to show how two immediately successive generations of pre-school children own - thanks to language - the rules of participation in social life and knowledge of the surrounding world. These two generations were the ones, who in the years 1980-83 were at a pre-school age and are now parents of children of the same age in 2010-2013. The analysis of the lexical score and language consciousness conducted from a thirty years' perspective gave unexpected results which suggest the need to revise Baudouin de Courtenay's thesis, according to which children's language is a kind of projection of adult users language representing the next generation. Made confrontations done show how many new words (which were not used by the previous generation, i.e. parents) appear in the lexical score and in consciousness of today pre-schools.

Keywords: children's language, vocabulary, word field, civilization changes 